ASLI QoL 2017
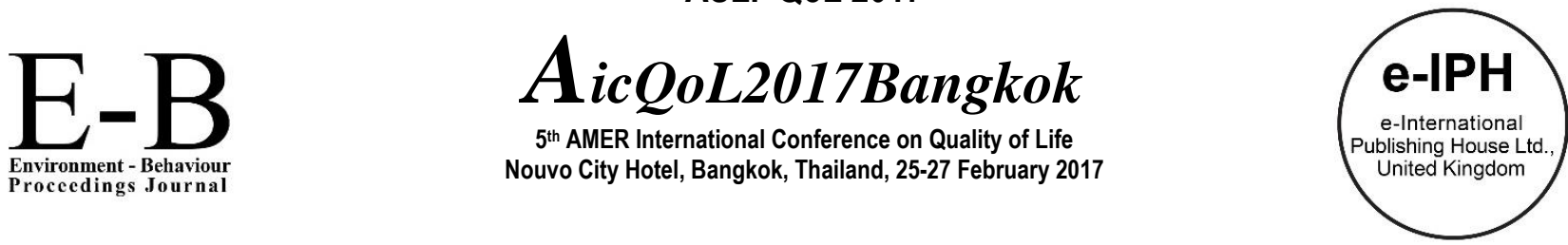

\title{
Implementation of Development Charge by Local Government of Malaysia: Implementation and challenges
}

\author{
Nor Azalina Yusnita Abdul Rahman*1, Mudirah Shaharudin ${ }^{2}$, Nurulhuda Ali3 ${ }^{3}$ Siti Fairuz Che Pin ${ }^{4}$ \\ ${ }^{1}$ Faculty of Architecture, Planning and Surveying, Universiti Teknologi Mara, \\ Cawangan Perak, 32610, Perak, Malaysia
}

\begin{abstract}
Local government plays a major role in property development in Malaysia. Local government in Malaysia is enacted under the Local Government Act 1976 to provide public facilities and amenities to local people as well as to control property development at the state level. At the current practice, development charges have been imposed on property project carried out in accordance with the provisions of Section 32 of the Town and Country Planning Act 1976 (Act 172). The main purpose of the development charges is to provide and improve infrastructures, public facilities, and amenities as well as the wellbeing of the development areas. The charges would be levied to developers once the project approved specifically for the conversion of land use, the increment of plot ratios and density, which would increase the land value. The purpose of this research is to identify the issues and challenges in the imposition of development charges to improvise the current methods practiced. This exploratory research aims to come out with the best practices on development charge. A qualitative semi-structured technique will be used that focus on six (6) states in Malaysia which consists of 26 local governments that are currently implementing the development charges. All the primary data were gathered from respondents will be analyzed by using content analysis through interview session. There were four (4) main issues reveals from this research whereby lack of awareness among developers top the chart. Meanwhile, amongst the challenges faced by the local government pertaining to the development charges implementation are to strengthen the implementation procedures of development charges as well as and to increase the understanding of the importance of development charges. The findings, therefore, will come out with full understanding towards the practice of development charges in Malaysia among government sector, developers and other relevant parties.
\end{abstract}

Keywords:development charge;local government; market value; developer

ISSN: 2398-4287@ 2017. The Authors. Published for AMER ABRA by e-International Publishing House, Ltd., UK. This is an open access article under the CC BYNC-ND license (http://creativecommons.org/licenses/by-nc-nd/4.0/). Peer-review under responsibility of AMER (Association of Malaysian Environment-Behaviour Researchers), ABRA (Association of Behavioural Researchers on Asians) and cE-Bs (Centre for Environment-Behaviour Studies), Faculty of Architecture, Planning \& Surveying, Universiti Teknologi MARA, Malaysia.

\subsection{Introduction}

Local government is an entity formed on the lowest level of the government's system for a country. According to Malcom W. Norris, 1974; Local government can be define as a benchmark of a city, suburb or a combination of both under government's administration for a state, abide by local law or code of conduct. In Malaysia, Local Government is divided by three (3) categories i.e. Majlis/ Dewan Bandaraya (City Hall), Majlis Perbandaran (City Council), and Majlis Daerah (District Council). The role and function played by Local Government are as stated in Part XI Section 73, Local Government Act 1976 (Act 171); responsible in providing and maintaining public areas, providing removal and disposal of solid waste and maintaining public health such as contagious diseases prevention.

In providing such services, sum amount of capital needed by Local Government to maintain and upgrading services in line with residents' need inside its administration. Local Government is permitted to gain financial revenue from several sources as an income

\footnotetext{
${ }^{*}$ Corresponding author. Tel.:

E-mail address: noraz335@perak.uitm.edu.my
}

ISSN: 2398-4287@ 2017. The Authors. Published for AMER ABRA by e-International Publishing House, Ltd., UK. This is an open access article under the CC BYNC-ND license (http://creativecommons.org/licenses/by-nc-nd/4.0/). Peer-review under responsibility of AMER (Association of Malaysian Environment-Behaviour Researchers), ABRA (Association of Behavioural Researchers on Asians) and cE-Bs (Centre for Environment-Behaviour Studies), Faculty of Architecture, Planning \& Surveying, Universiti Teknologi MARA, Malaysia

DOI: http://dx.doi.org/10.21834/e-bpj.v2i5.709 
according to Act 171 Part V section 39. The source of income can be derived from properties rental, processing fees, investment and saving profit, annual grants, donation and contribution, fines and assessment (Zahari Ab. Rashid, 1991).

Through various kind of reform in public administration in Malaysia, in line with the new era of science and technology and globalization, this situation demanded all level of government's administration to be in the best shape to give full commitment. In public management, as the frontline in serving and facilitate the public, Local Government is demanded to be in the highest level of efficiency.

\subsection{Research Background}

Development can be defined as an effort to achieve advancement (Kamus Dewan, 2000) or change within time scale (McMillan English Dictionary, 2002). Development of certain territory can be said as an effort to increase and fixing economic extent in certain area over time. Land development in such area need to be control in order to protect and secure the surrounding, individual and government. In case of land development, developers need to consult Land Office as the purpose of Land Office is to handle all sort of things pertaining to land in district area, whereas in the case of land development, developer or individual have to consult local planner in Local Authority Office because it deal with zoning, local plan, policy of plan and so on.

Development of land in Malaysia must undergo all the procedures and provision related like 'Akta Perancangan Bandar Dan Wilayah 1976 (Akta 172) and amendment (Akta 1129) as well as 'Kanun Tanah Negara 1965 (Akta 56), Akta (perancangan) Wilayah Persekutuan 1982 (Akta 267) for Kuala Lumpur. Some other laws related will also effective for approval in land development (if related) as specified by local planner authority.

Issues related to development costs pertaining to city development control have drawn attention to researcher all over the world to scientifically find the respond from public opinion from various sides. This research conducted to show practice as well as implementation by government sectors in district level pertaining to implementation of charge for land development purposes.

\subsection{Problem Statement}

Urbanization process is a process that is so dynamic and have ongoing and a lasting impact (Ahris Yaakup 2004). This process involves a change in the socio-economic and physical development of a township. In the concept of sustainable development $/$ sustainability has begun to be applied in the development planning process when the Sixth Malaysia Plan (1991- 1995) reviewed subsequently used as a basis in the preparation of the Seventh Malaysia Plan (1996) with emphasis on balanced and sustainable development.

Sustainable urban development is a process of joint decision-making by stakeholders in the planning of the city such as the Local Authorities (PBT), an association of local businesses, NGOs and consumers, to ensure that economic activity, welfare (including health) and ecosystem all together are given consideration to ensure that present and future generations' needs fulfilled on an ongoing basis. As the authorized body through various acts, policies, methods and so the role of local authorities is seen as critical in achieving the goal of sustainable development in the country. Some states have gazette the development charge, a move initiated by Kuala Lumpur City Hall subsequently practiced also by some other states like Selangor, Perak, Kedah and Kelantan. The purpose of the imposition of this charge is to cover the costs and improve the provision of infrastructure and public facilities for the area due to given planning permission.

Basically the development charge is a form of cash collections related to development provided for under Section 32 of Act 172. This charge imposed if there are Local plans (RT) or changes to RT causing an increase in the value of land. The charges levied for development affecting the changes of land use, density and floor area.

All of the land development application for planning permission must be submitted to One Stop Centre (OSC) unit of local authorities to be processed by the government agencies involved. This method began to be noticed by most local authorities to explore opportunities to increase income and to preserve the development thus the implementation of development charges is seen as a feasible alternative.

Most of the states use a similar method as implemented by Selangor state; however, the approach of each state can be different according to suitability and requirements of each state. There are several things that are still being discussed by the executor. Among the issues often raised is the rate of charge (Article 4) are subject to a certain area is not really suitable in term of real needs of the charges levied.

The issue of payment methods also rose where the rate of interest on installment payment seems not so appropriate and there are objections from developers and the local authorities themselves. Selangor set $8 \%$ on the amount of charge on the remaining installment, while Perak only fix the rate of interest but the amount is up to the local authority and Kedah is not imposing interest rates on installment payment.

There is no consistency between the local authorities in term of the use of the development charge, according to Act 172 state that the collection of the development charge is to be deposited into developer special account i.e. 'Tabung Caj Pemajuan' and will be used to provide public facilities and upgrading areas of development but there are also local authorities which include the proceeds to the account of the Consolidated Fund where it is used for operating expenses and needs to be spent in the current year. While PBT Perak divided the collection which $40 \%$ of the development charges are deposited into account namely 'Tabung Caj Pemajuan', while another $60 \%$ were deposited into the Consolidated Fund to accommodate the cost of management and also staff training program. 


\subsection{Literature Review}

A property development in Malaysia should follow the procedures and provisions of the Town and Country Planning Act 1976 (Act 172) and its amendments (Act 1129) and the National Land Code 1965 (Act 56), Act (planning) Federal Territories Act 1982 (Act 267 ) to Kuala Lumpur. Other laws related will also be effective for implementing the terms of the land development approval (if applicable) as prescribed by local planning authorities in a development approval.

Issues relating to the impact of the development costs of planning control have attracted the interest of many researchers around the world to carry out scientific research to gain certainty about the opinions and views of the various parties, however, this type of research is very less in Malaysia. In order to fill the knowledge gaps in this case in Malaysia, introduction to this study begins with description of the important things that are involved in the development of land and followed by the issues and challenges that affect the development of the land.

\subsection{System Development Land in Malaysia}

Planning can be defined as to do something in the future. In simple terms, the planning is carried out to ensure that the future will be traversed in a comfortable and peaceful. In the aspect of City Planning, to design a future with a vision to create a harmonious and prosperous area is the aim. There are balance between the people and the environment. Briefly provisions in the field of urban conservation as outlined by Act 172 may be divided into three main forms:

i. Planning permission

Planning permission (Kebenaran Merancang) must be obtained from the Local Planning Authority (LPA) of an area before a development is conducted in an area.

According to the provisions of Section 19 (1) of the Town and Country Planning Act 1972 Act 172, if an area is to be developed for planning permission must be submitted to the Local Planning Authority (LPA). For areas that do not have local government, the local planning authority for the area is the Town and Country Planning Department (State) in the state where the area is situated.

Any development carried out without first obtaining a "planning permission" of the parties concerned (either LPA or the Director of JPBD of a state) is an offense. Parties that found out guilty can be charged. If convicted, the penalty can be imposed.

ii. Development plans

Town and Country Planning Act 1976 (Act 172) provides a comprehensive development system. Through this system, the National Physical Plan prepared by the Director General of the Department of Town and Country Planning (DTCP), the Structure Plan prepared by the Director of the State DTCP while LPA is also required to prepare local plans.

According to the provisions of Act 172, Section 12 (3) (a) (viii) states that a Development Plan (planning Plan) to create a formula that contains details deemed appropriate by the LPA on the proposal to maintain and beautify the characteristics of various buildings in the local plan area. Structure Plan is a written statement of policy and general proposals for the promotion and development of land, including measures improving the environment in terms of physical and others in an area, however, the details of these provisions can only be found in the local plan.

\subsection{Legal Land Development}

Development land in Malaysia from the legal perspective, there are various provisions of the act relating to this field other than the primary legislation of the Town and Country Planning Act (Act 172). Among the acts / laws that are also affiliated with the Town and Country Planning are:

\begin{tabular}{|c|c|}
\hline Local Government & $\begin{array}{l}\text { Local Government Act } 1976 \text { (Act 171) } \\
\text { - Federal Territory Planning Act } 1962 \text { (Act 267) } \\
\text { - Langkawi Development Authority Act, } 1990 \text { (Act 423) } \\
\text { - Labuan Corporation Act } 2001 \text { (Act 609) } \\
\text { - Town Boards Enactment (Cap 137) }\end{array}$ \\
\hline Land & $\begin{array}{l}\text { - National Land Code } 1965 \text { (Act 56) } \\
\text { - Land Acquisition Act } 1960 \text { (Act 486) } \\
\text { - Strata Ownership Act } 1985 \text { (Act 318) } \\
\text { - Land Conservation Act } 1960 \text { (Act } 385\end{array}$ \\
\hline Building & $\begin{array}{l}\text { - Road Drainage and Building Act } 1974 \text { (Act 133) } \\
\text { - } 1984 \text { Undang Undang Kecil Bngunan Seragam }\end{array}$ \\
\hline d) Environment & • Environmental Quality Act 1974 (Act 127) \\
\hline Infrastructure and Utilities & $\begin{array}{l}\text { - Electricity Supply Act } 1990 \text { (Act 447) } \\
\text { - Sewerage Services Act } 1993 \text { (Act 508) }\end{array}$ \\
\hline Housing & $\begin{array}{l}\text { - Act on Minimum Standards of Housing and Amenities Act } 1990 \text { (Act 446) } \\
\text { - The Housing Developers (Control and Licensing) Act } 1966 \text { (Act 118) }\end{array}$ \\
\hline Service & - Fire Services Act 1988 (Act 341) \\
\hline
\end{tabular}




\begin{tabular}{|l|l|}
\hline & $\bullet$ Care Centres Act 1993 (Act 506) \\
\hline Heritage & $\bullet$ Antiquities Act 1976 (Act 168) (JBBD, 2003) \\
\hline
\end{tabular}

\subsection{Development Charges By Local Authorities in Malaysia (comparison imposition by each state)}

Development charges are paid by local authorities to any applicant if there is a development of the Local Plan or Local Plan Amendment landowners on planning approval resulting in land value increment due to following reasons: 1. Approval of the development involved the conversion of land use zones that have raised the value of land.

2 There is a surplus of floor area of the plot ratio specified in the development plan.

3. There is a surplus of units above the average density residential development specified in the order.

The aim of the development charge is to cover the cost of the provision of providing and improving infrastructure and facilities in the region as a result of granted planning permission. There are two related acts development charge of Town and Country Planning Act 1976 and the development charges under Act 267, Act (Planning) Act 1982. The development charge is imposed for excess and surplus floor space of residential units as well as the lack of parking space at the prescribed rates.

Table 2:

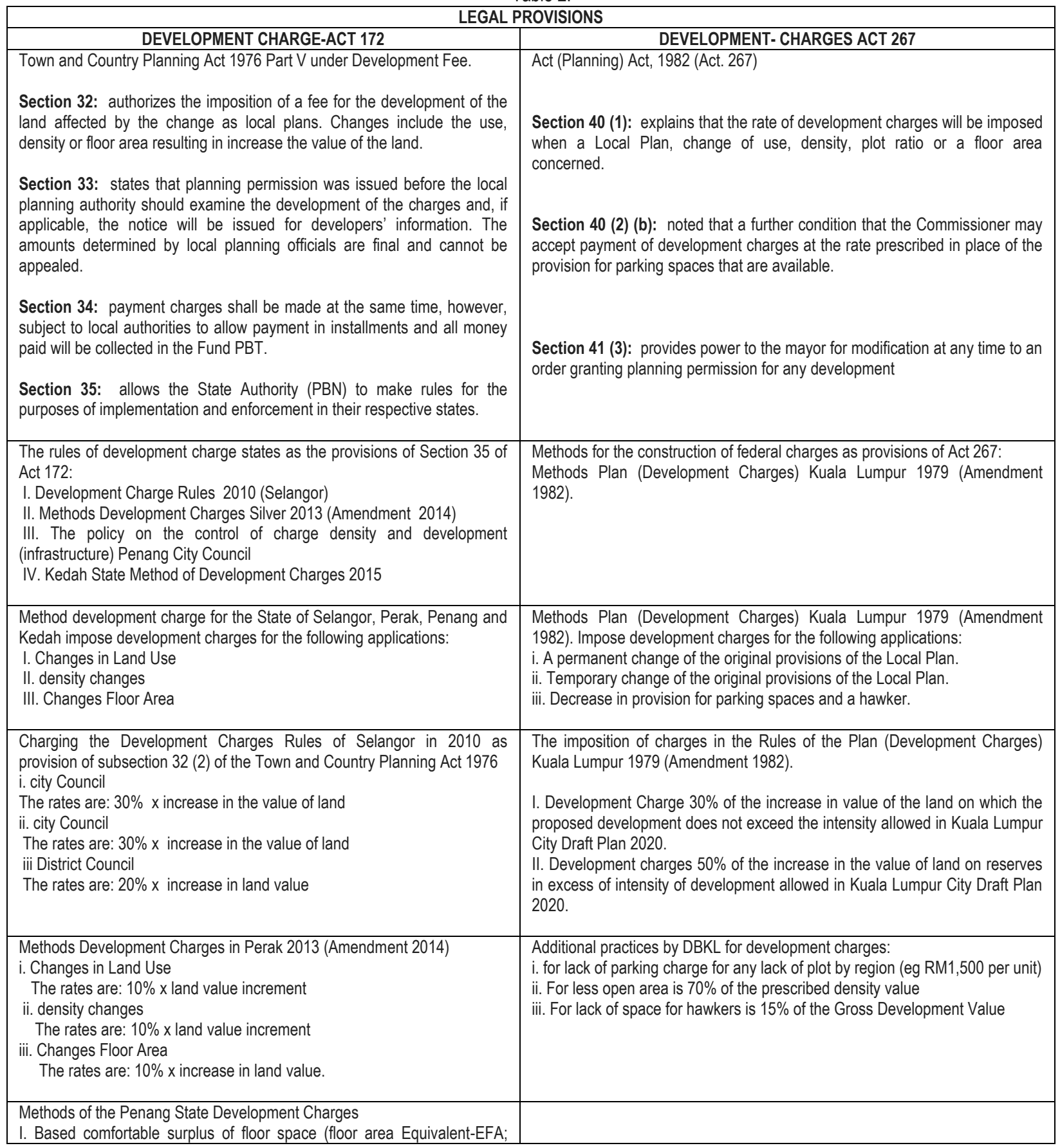




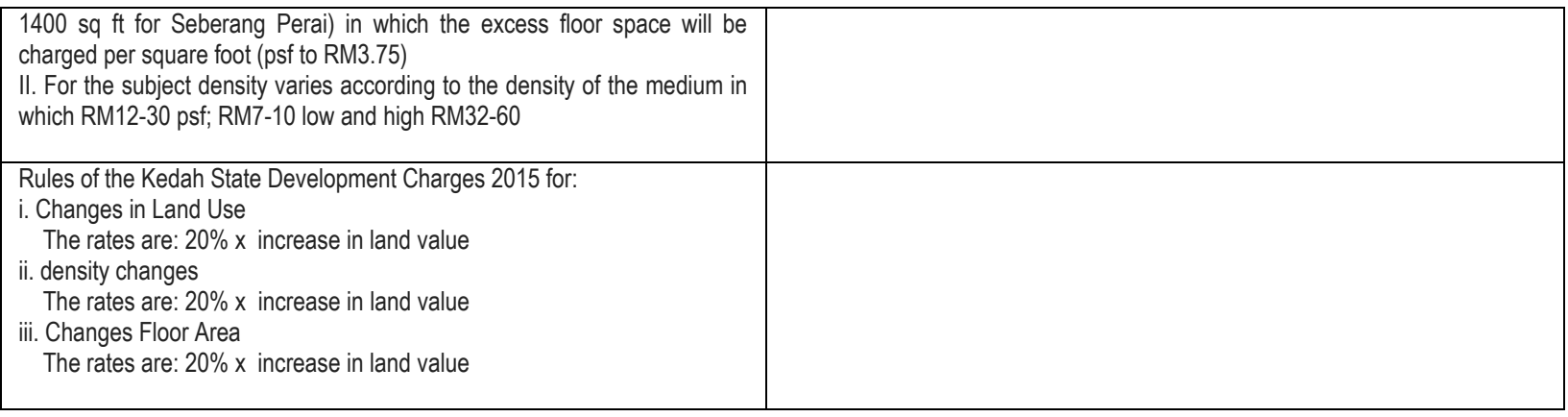

\subsection{Research Methodology}

The research methodology is an overall review process including an initial stage through to the final stage of the study. In addition, the structure of the research methodology is based on convergence towards the achievement of the goals and objectives of the study. There are three main stages of the methodology in this study, namely; the study of theoretical, empirical studies that include the collection of data and information as well as the analysis and evaluation of data.

\subsection{Stage 1- Theoretical Studies}

This stage is divided into two parts, namely the preliminary study and the study of literature. In the preliminary study, early research and understanding obtained from reference materials on methods development charge by the Local Authority Malaysia is needed. This study was initiated to identify the charges that have been enacted by States, implementation by local authorities on the issues and problems faced at the local and global level, then continue with the execution scenario and dealt with the implementation of corporate governance practices that are ideal for application in the management of development charges by local authorities of Malaysia.

\subsection{Stage 2- Empirical Study}

At this stage, for collection and acquisition of data, insights from experts in the executive group management development charge will be collected through interviews between researchers with the parties involved. In addition, the comparison of the governance practices adopted by Malaysia and foreign countries chosen will also be compared with the principles and indicators of existing governance adopted by them in implementation of this charge.

\subsection{Stage 3-Analysis and Evaluation Data}

At this stage, all data and information obtained either primary and secondary data will be analyzed through qualitative methods by using software called Atlas.ti and translated in the form of graphics such as statistics, charts, graphs, and tables. In order to measure framework of governance practices, initial attempt has been done to implement the institutions and parties concerned.

\subsection{Research Area}

The selection of the research area is a very important aspect in the case study method. Although the case studies that are intended can consist of various types of programs, events, activities, processes or individuals but it depends on the needs of the study. According to Tayie (2005), area studies / investigations usually show a behavior or phenomenon to study, to understand the implementation and issues related to the local authority for the state which has proclaimed the development charge has been selected as the area of research. Data collection was conducted using qualitative methods.

\subsection{Primary data}

The primary data is the raw data obtained by researchers through several methods. There are two ways to obtain i.e. observation methods through discussion by a 'focus group' and the method of interview respondents or 'depth interviews' and later will be analyze thoroughly.

\section{i) Focus Group}

This approach enables the executor among the staff of local authorities to gather and talk about the issues and challenges in the implementation of development charge according to the method of development charge of their respective states. Topics of discussion include the procedures for the implementation of development charges, justification for the imposition of the charges, a flow chart of work, issues and challenges in relation to the imposition of charges relating to the planning approval process.

Program courses / workshops

- Workshop on Imposition of Charges imposed for approval and implementation of land development (19-21 July 2016)

- Development Charges Implementation Workshop: Methods and Procedures (9-11 August August 2016)

- Seminar on Implementation of Development Charges In Ireland: Implementation and Challenges (5 to 7 October 2016) 


\section{ii) An in-depth interview}

Some local authorities will be selected by category i.e. city, municipal and district levels. Responder criteria are examined for determining the differences between the workload, application rates, staffing and procedures. Issues and challenges faced by the department in charge of development also been viewed.

\subsubsection{Sampling}

To obtain the data, sampling methods should be framed first. The sample is set to be the source of the information required by the researcher. For example, the State of Perak had 15 for PBT established at the district level, the group is known as the 'population' and 5 local authorities of the group chosen for investigation, and thus this five PBT become a sample. For the purposes of this study PBT for states that have implemented development charge is considered as population. The five states are Federal Territory of Kuala Lumpur, Selangor, Perak, Penang, Kedah and Kelantan. The number of local authorities in each country is shown in Table 1.

Table 3: Number of population is as follows:

\begin{tabular}{|c|c|c|c|c|c|}
\hline \multirow{2}{*}{ NO } & \multirow{2}{*}{ STATE } & \multicolumn{2}{|c|}{ LOCAL AUTHORITY BY CATEGORY } & \multirow{2}{*}{ TOTAL } \\
\cline { 3 - 6 } & & CITY & MUNICIPAL & DISTRICT & \\
\hline 1 & $\begin{array}{c}\text { Federal } \\
\text { State }\end{array}$ & 1 & - & - & 1 \\
\hline 2 & Selangor & 2 & 6 & 4 & 12 \\
\hline 3 & Perak & 1 & 4 & 10 & 15 \\
\hline 4 & $\begin{array}{c}\text { Pulau } \\
\text { Pinang }\end{array}$ & 1 & 1 & & 2 \\
\hline 5 & Kedah & 1 & 3 & 7 & 11 \\
\hline & & \multicolumn{2}{|c|}{ TOTAL } \\
\hline
\end{tabular}

Source: Official website of each state

Given the relatively large number of the population, researchers must determine which groups could be targeted as a sample. This scenario due to constraints such as large size of population, diverse and covers a large area makes it difficult for researchers to do so. Find and contact all members of the population will cost time and expense. The researchers had to select a sample to be investigated. This study has shortlisted the number of respondents for the purpose of sampling. Sampling methods that have been implemented are Non Probability Sampling (not random), the procedure is normally used by the researcher in qualitative research. Non-probability sampling involves selecting samples from a population that has been identified based on the criteria.

Table 4:

\begin{tabular}{|c|c|c|c|}
\hline \multirow[t]{2}{*}{ Development Charge Rules } & \multicolumn{3}{|c|}{ Local Authorities } \\
\hline & City & Municipal & District \\
\hline Wilayah Persekutuan & $\begin{array}{c}\text { Dewan Bandaraya Kuala } \\
\text { Lumpur }\end{array}$ & - & - \\
\hline Selangor & Majlis Bandaraya Shah Alam & Majis Perbandaran Subang Jaya & Majlis Daerah Kuala Langat \\
\hline Perak & Majlis Bandaraya Ipoh & Majlis Perbandaran Kuala Kangsar & Majilis Daerah Gerik \\
\hline Kedah & Majlis Bandaraya Alor Setar & Majlis Perbandaran Sungai Petani & Majis Daerah Bandar Baru \\
\hline Kelantan & & Majlis Perbandaran Kota Bharu & Majlis Daerah Pasir Mas \\
\hline Pulau Pinang & Pulau Pinang & $\begin{array}{c}\text { Majis Perbandaran Seberang } \\
\text { Perai }\end{array}$ & - \\
\hline Jumlah & 4 & 5 & 4 \\
\hline
\end{tabular}

\subsection{Secondary Data}

Secondary data is data collected based on previous studies on any writing related disclosures problem assigned. These data were obtained from sources such as Town and Country Planning of the provision of Section 134 that allows the state government provide methods Development Charges to be implemented in their respective states, the method of development charges Dewan Bandarayara Kuala Lumpur, Selangor, Perak, Penang and Kedah, newspaper articles and books, monographs, journals, seminar paper, the results of previous studies and so on. 


\subsection{Findings}

A qualitative semi-structured technique will be used that focus on six (6) states in Malaysia which consists of 26 local governments that are currently implementing the development charges. All the primary data were gathered from respondents will be analyzed by using content analysis through interview session. There were four (4) main issues reveals from this research whereby lack of awareness among developers top the chart.

\begin{tabular}{|c|c|c|c|}
\hline STATE & SECTION 3 (charging) & ISSUES AND PROBLEMS & PROPOSED SOLUTION \\
\hline $\begin{array}{l}\text { Perak State Development } \\
\text { Charges Methods } 2013 \\
\text { Perak State Development } \\
\text { Charges Methods (Amendment) } \\
2014\end{array}$ & $\begin{array}{l}\text { Three types of changes can be charged } \\
\text { forwarding: } \\
\begin{array}{l}\text { - } \\
\text { - } \quad \text { Change in land use; } \\
\text { or } \\
\text { - Change in floor area. }\end{array}\end{array}$ & $\begin{array}{l}\text { Terms of Exchange Real Estate After } \\
\text { Imposition of Date, methods of Imposed } \\
\text { Development Charges }\end{array}$ & $\begin{array}{l}\text { Any change after the date } \\
\text { of } \\
\text { gazette of the land rules } \\
\text { will not be applied to } \\
\text { development charges. If } \\
\text { the changes are in real } \\
\text { conditions and zoning } \\
\text { ordinance in Local Plan } \\
\text { (LP) does not cause any } \\
\text { increase in the value of } \\
\text { land. } \\
\text { Changes in the value of } \\
\text { land in the presence of } \\
\text { LP compared with the } \\
\text { value of the land based } \\
\text { on the use of the } \\
\text { ownership. } \\
\text { The use of the title is a } \\
\text { reference to the current } \\
\text { title created Planning } \\
\text { Permission (PP). } \\
\text { If, before the application } \\
\text { of PP is created, } \\
\text { developers have already } \\
\text { made the conversion } \\
\text { terms of real estate and } \\
\text { real conditions of the new } \\
\text { line with the current } \\
\text { zoning-out have } \\
\text { increased the value of } \\
\text { land, the development } \\
\text { charges CAN NOT be } \\
\text { imposed }\end{array}$ \\
\hline
\end{tabular}

Issue 2: The Imposition Of Rates

\begin{tabular}{|c|c|c|c|c|}
\hline $\begin{array}{l}\text { DEVELOPMENT } \\
\text { CHARGE / }\end{array}$ & \multicolumn{2}{|c|}{ IMPOSITION OF CHARGES } & ISSUES & PROPOSED SOLUTION \\
\hline \multirow{3}{*}{$\begin{array}{l}\text { Development Charges } \\
\text { Rules } 2010\end{array}$} & City & $30 \% \times$ increasing the value of land & \multirow{3}{*}{$\begin{array}{l}\text { Charging } 20 \% \text { of PBT are not } \\
\text { suitable because the area is } \\
\text { smaller and needs PBT } \\
\text { management costs are lower } \\
\text { compared to municipal and local } \\
\text { authorities of the city. }\end{array}$} & \multirow{3}{*}{$\begin{array}{l}\text { A review of the rate of charge } \\
\text { for all categories of local } \\
\text { authorities to enable local } \\
\text { authorities to obtain the same } \\
\text { amount of charge by the city } \\
\text { and the municipality. }\end{array}$} \\
\hline & Township & $30 \% \times$ increase the value of land & & \\
\hline & District & $20 \% \times$ increase the value of land & & \\
\hline $\begin{array}{l}\text { Perak State } \\
\text { Development Charges } \\
\text { Methods 2013; } \\
\text { Perak State } \\
\text { Development Charges } \\
\text { Methods (Amendment) } \\
\text { Order } 2014\end{array}$ & & $\begin{array}{l}10 \% \text { x increase in Land value } \\
\text { (all categories in PBT) }\end{array}$ & $\begin{array}{l}\text { Imposition of rates are very low } \\
\text { and do not reflect the cost of } \\
\text { providing public facilities. }\end{array}$ & $\begin{array}{l}\text { The imposition of charges is } \\
\text { also taking into consideration } \\
\text { the costs related to the } \\
\text { provision of facilities } \\
\text { requirements as required } \\
\text { under Act } 172 \text {. }\end{array}$ \\
\hline \multirow{2}{*}{$\begin{array}{l}\text { Kedah State } \\
\text { Development Charges } \\
\text { Methods } 2015\end{array}$} & Residence & $10 \% x$ increase in land value & \multirow{2}{*}{$\begin{array}{l}\text { - Most of the land is paddy fields } \\
\text { involves a high cost of land } \\
\text { reclamation } \\
\text { - There are development that be }\end{array}$} & \multirow{2}{*}{$\begin{array}{l}\text { Charge imposition must take } \\
\text { into account the cost of land } \\
\text { development in order to } \\
\text { reduce the effect of the }\end{array}$} \\
\hline & Non-residence & $20 \% \times$ increase in land value & & \\
\hline
\end{tabular}




\begin{tabular}{|l|l|l|l|l|}
\hline & & & done in pocket development & $\begin{array}{l}\text { increase in costs to be borne } \\
\text { by the developer, however, } \\
\text { developers have stated in the } \\
\text { application reclamation costs } \\
\text { necessary to facilitate the } \\
\text { the local } \\
\text { calculation by } \\
\text { authority for the imposition of } \\
\text { development charges. }\end{array}$ \\
\hline
\end{tabular}

Issue 3: Interest Rate / penalty payment on installments

\begin{tabular}{|c|c|c|c|}
\hline State & Assay for installment payments & ISSUES AND PROBLEMS & PROPOSED SOLUTION \\
\hline $\begin{array}{l}\text { Development } \\
\text { Charges Rules } 2010\end{array}$ & $\begin{array}{l}\text { The imposition of an interest rate of } 8 \% \text { of } \\
\text { the total charge }\end{array}$ & \multirow{3}{*}{$\begin{array}{l}\text { Imposition of rates on the amount of the } \\
\text { charges is not suitable. Method of } \\
\text { payment in installments is RM100 } 000 \\
\text { and above for the state of Selangor and } \\
\text { Kedah. Kedah also allowing for an } \\
\text { installment payment of RM50,000 and } \\
\text { RM } 10,000 \text { for Kelantan. } \\
\text { For the state of Selangor, Perak and } \\
\text { Kedah number of installments is } 3 \text { times a } \\
\text { term not exceeding one year, while } \\
\text { Kelantan provide installment payment of } 4 \\
\text { times in } 1 \text { year. }\end{array}$} & $\begin{array}{l}\text { The term 'interest' is not suitable } \\
\text { because it does not reflect the } \\
\text { Islamic values and is } \\
\text { guestionable from the point of }\end{array}$ \\
\hline $\begin{array}{l}\text { Perak State } \\
\text { Development } \\
\text { Charges Methods } \\
\text { 2013; } \\
\text { Perak State } \\
\text { Development } \\
\text { Charges Methods } \\
\text { (Amendment) Order } \\
2014\end{array}$ & $\begin{array}{l}\text { The imposition of interest on the total } \\
\text { charge }\end{array}$ & & $\begin{array}{l}\text { Sharia. } \\
\text { Application for installment } \\
\text { payment is allowed by the Form } \\
\text { B, it was not suitable if the } \\
\text { payment is subject to any penalty } \\
\text { rates because the application has } \\
\text { been approved for the } \\
\text { installment. } \\
\text { Use of the term 'interest' should be }\end{array}$ \\
\hline $\begin{array}{l}\text { Kedah State } \\
\text { Development } \\
\text { Charges Methods } \\
2015\end{array}$ & $\begin{array}{l}\text { There are no interest rates or the } \\
\text { imposition of any penalty upon request } \\
\text { installment payment or late payment } \\
\text { charges by the applicant }\end{array}$ & & $\begin{array}{l}\text { changed to fines and rates } \\
\text { charged on late payments by the } \\
\text { applicant as payment procedures } \\
\text { allowed. } \\
\text { It is not fair if no penalty imposed } \\
\text { as in the case of Kedah where } \\
\text { there is a case of late payments } \\
\text { to local authorities. }\end{array}$ \\
\hline
\end{tabular}

Issue 4: The Reduction and Exemption Of The Payment Of Development Charges

\begin{tabular}{|c|c|c|c|}
\hline State & $\begin{array}{l}\text { REDUCTION AND EXEMPTION OF } \\
\text { PAYMENT }\end{array}$ & ISSUES AND PROBLEMS & PROPOSED SOLUTION \\
\hline $\begin{array}{l}\text { Development Charges Rules } \\
2010\end{array}$ & \multirow{5}{*}{$\begin{array}{l}\text { No reduction or exclusion of } \\
\text { development charge may be made by } \\
\text { local authorities except as the types of } \\
\text { development specified in the rules. }\end{array}$} & \multirow{5}{*}{$\begin{array}{l}\text { - PP Application from individuals to } \\
\text { conversion and subdivision is not to build } \\
\text { a building cannot afford to pay } \\
\text { development charges }\end{array}$} & \multirow{5}{*}{$\begin{array}{l}\text { Review the types of applications } \\
\text { that are charged with taking } \\
\text { individual application for the } \\
\text { purposes of inheritance either } \\
\text { exempt or subject to a charge rate } \\
\text { lower than the charge for } \\
\text { developers and profit-oriented. }\end{array}$} \\
\hline $\begin{array}{l}\text { Perak State Development } \\
\text { Charges Methods 2013; } \\
\text { Perak State Development } \\
\text { Charges Methods } \\
\text { (Amendment) Order } 2014\end{array}$ & & & \\
\hline & & & \\
\hline $\begin{array}{l}\text { Kedah State Development } \\
\text { Charges Methods } 2015\end{array}$ & & & \\
\hline $\begin{array}{l}\text { Methods Development Charges } \\
\text { (Negeri Kelantan) } 2015\end{array}$ & & & \\
\hline
\end{tabular}

\section{Challenges}

The researcher's observations have revealed few challenges faced by the Local Authorities in implementing the development charges. Among the challenges are lack of knowledge regarding the implementation of the charges. Many of developers (applicants) are unaware of the purpose of these charges and always have the opinion that it will give impact to the hiking of development costs and property prices. On top of that, other revealed challenges are lack commitment of the applicants to pay the charges to Local Authority, as well as unsystematic work procedures pertaining to the implementation of the charges by Local Authorities. Nevertheless, based on the analysis of the findings have revealed the following main challenges.

i. Act as new income sources

Development charges are the other mechanism for local authority to generate more income for the purpose of providing and maintaining the public facilities and amenities (DBKL, 2016). These charges are being charged based on the changes of 
land value in accordance to the gazetted local plan of each local authority. The main issues arose was whether the local authorities are capable to generate income based on these charges in order to provide the above said facilities and amenities. The main concern was due to the imbalance of development pace within the state area. Some area especially within town centre may face rapid development hence generating more income for the particular authority, and other outskirt areas may have slow development pace thus resulting to the less income generated. This scenario will resulting to the imbalance of authorities account within the same state. Thus, the effectiveness of development charges to act as a new source of income does not meet. The collection pattern of development charges are shown in Table 4.

ii. Effective work procedures.

The working procedures for development charges are involving four main departments namely One Stop Centre (OSC), Planning Department, Valuation Department, as well Financial Department. It will start off with applying the planning permission and planners will do the first evaluation of the applicable charges followed thru with assessment by valuers and finally collection by financial department. Each local authority would have different timeframe for the working procedures. The main issues pertaining to this matter was the ineffectiveness of the work flow especially those states that just implementing the development charges such as Kedah and Kelantan. The ultimate challenges for these states were to ensure the collections are successfully collected by the authority. Factors that contributing to the above said matter were ineffective working procedures at authority's level as well lack of commitment by developers in paying the charges.

\subsection{Conclusion}

DBKL has given the best example in this practice as it is shown in the areas within its jurisdiction have experience a very rapid development pace and good public facilities and amenities provided within the area since 1970. This should set as a benchmark to other authorities especially those states who were just implementing the development charges such as Selangor, Perak, Kedah and Kelantan. Nevertheless, the above mentioned challenges have become the main obstacles to these authorities in order to achieve the objectives of implementing development charges as new source of income as well as in providing better facilities and amenities hence creating comfortable ambience to the public within their jurisdiction. Therefore, new best practices for development charges implementation seems very crucial and requires an immediate remedial action in order to ensure the objectives of implementing this charges to be successfully achieved.

\section{References}

Ahmad Atory Hussin, 1991: Kerajaan Tempatan: Teori dan Peranan Di Malaysia. Kuala Lumpur: Dewan Bahasa dan Pustaka.

Goh Ban Lee, 1991: Urban Planning In Malaysia: History, Assumptions and Issues. Petaling Jaya, Selangor: Tempo Publishing.

Ismail Ibrahim, 2002: Pengenalan Kepada Prosedur Dan Amalan Perancangan Bandar Dan Desa. Kuala Lumpur: Jabatan Perancangan Bandar dan Desa. Tidak Diterbitkan.

Lee Lik Ming,1990: Town and Planning In Malaysia: History and Legislation. Pulau Pinang. Penerbit Universiti Sains Malaysia.

Majlis Perbandaran Melaka Bandaraya Bersejarah, 2002: Draf Pelan Tindakan Kawasan Pemeliharaan Zon 1 MPMBB. Melaka: Unit Konservasi

Majlis Perbandaran Pulau Pinang, 1985: Laporan Pemeriksaan Rancangan Struktur Majlis Perbandaran Pulau Pinang. Pulau Pinang: Jabatan Perancangan Bandar dan Pembangunan

Majlis Perbandaran Pulau Pinang: 2000: Draf Rancangan Struktur (Pengubahan) Majlis Perbandaran Pulau Pinang. Pulau Pinang: Jabatan Perancangan Bandar dan Pembangunan

Malaysia, 1976: Akta Benda Purba (Akta 168). Kuala Lumpur: Jabatan Penerbitan Negara

Malaysia, 1998: Akta Kerajaan Tempatan (Akta 171). Kuala Lumpur: Jabatan Penerbitan Negara

Malaysia, 1998: Akta Perancangan Bandar Dan Desa (Akta 172). Kuala Lumpur: Jabatan Penerbitan Negara

Perbadanan Muzium Melaka, 1996: Pelan Tindakan Kawasan Warisan Melaka: Jalan Tun Tan Cheng Lock dan Jalan Gelanggang. Melaka: Perbadanan Muzium Melaka

Phang Siew Nooi, 1996: Sistem Kerajaan Tempatan Di Malaysia. Kuala Lumpur: Dewan Bahasa dan Pustaka

Yazid Saleh, 2003: Pemuliharaan Bangunan Warisan: Kajian Kes di Melaka dan Pulau Pinang Rancangan Pengajian Perbandaran dan Perancangan, Fakulti Sastera dan Sains Sosial, Universiti Malaya. Tidak Diterbitkan. 